\title{
Climate Variability in the Sudano-Guinean Transition Area and Its Impact on Vegetation: The Case of the Lamto Region in Côte D'Ivoire
}

\author{
A. Diawara, ${ }^{1,2}$ F. Yoroba, ${ }^{1,2}$ K. Y. Kouadio, ${ }^{1}$ K. B. Kouassi, ${ }^{1,2}$ \\ E. M. Assamoi, ${ }^{1}$ A. Diedhiou, ${ }^{3}$ and P. Assamoi ${ }^{1}$ \\ ${ }^{1}$ Laboratory of Atmosphere Physics and Fluid Mechanics, University F.H.B. of Cocody-Abidjan, 22 BP 582 Abidjan 22, Cote D’Ivoire \\ ${ }^{2}$ Geophysical Station of Lamto, 01 BP 398 Abidjan 01, Cote D'Ivoire \\ ${ }^{3}$ LTHE-IRD, University of Grenoble, BP 53, 38041 Grenoble Cedex 9, France
}

Correspondence should be addressed to A. Diawara; diawara_adama@yahoo.fr

Received 19 August 2013; Accepted 14 December 2013; Published 13 February 2014

Academic Editor: Luis Gimeno

Copyright @ 2014 A. Diawara et al. This is an open access article distributed under the Creative Commons Attribution License, which permits unrestricted use, distribution, and reproduction in any medium, provided the original work is properly cited.

Based on unique 50-year datasets from 1962 to 2011 , this study diagnoses the variability of climate at Lamto $\left(6.13^{\circ} \mathrm{N}, 5.02^{\circ} \mathrm{W}\right)$ in Côte d'Ivoire. A combined pluviothermal index is used to identify climate regions of West Africa. The interdecadal change of the climate is analyzed along with a discussion on the West African Monsoon (WAM) circulation. The impact of vegetation is also analyzed. It is shown that Lamto has mainly a subhumid climate but, in some particular years, this area has a humid climate. Two decades (1962-1971 and 2002-2011) exhibit rainfall excess and the last three ones (1972-1981, 1982-1991, and 1992-2001) show a rainfall deficit that affected West Africa in the early 1970s. The meridional wind field from $1000 \mathrm{hPa}$ to $700 \mathrm{hPa}$ is used to study the WAM variability. The level of the WAM is the lowest $(\sim 860-890 \mathrm{hPa})$ during the active period of the northern wind coming from the Sahara desert (November-February). During 1962-1971 and 2007-2009, the depth of the monsoon at Lamto reaches $300 \mathrm{hPa}$ with an increase in the rainfall. A relationship between potential evapotranspiration and the climate highlights rainfall deficit in 1969 and rainfall excess in 2001-2011.

\section{Introduction}

Temperature and rainfall are generally used to delimit climatic zones in tropical regions since various impacts of rainfall regime have been observed over many regions of West Africa, which have different temperature variations [1-6]. That implies (i) a relationship between the rainfall amount and temperature variations and (ii) delimitation of climatic periods using both variables [2, 7]. However, many classification tests commonly used to define climatic periods are often empiricism methods. Some of them are simple, flexible, and easy to use, as the method proposed by Moral [2] and applied by Lecordier [7] over the 1962-1971 period in a study case of the Lamto region $\left(6.13^{\circ} \mathrm{N} ; 5.02^{\circ} \mathrm{W}\right)$ in Côte d'Ivoire. This last author considered four months types, respectively, noted rainy month $(\mathrm{r})$, wet month $(\mathrm{w})$, dry month (d), and arid month (a) to define the annual cycle. For the mean 1962-1971 period, Lecordier [7] found five rainy months (April, May, June, July, and September), four wet months (March, August, October, and November), two dry months (February and December), and one arid month (January). Moral [2] also performed the annual pluviothermal index $\left(I_{a}\right)$ based on rainfall and temperature relationships. The climatic periods found with this method were coincident with other methods [8].

Lamto is a regular subhumid region subdivided in four seasons [7]. This climate has great interannual variability [9], which could influence physical and biological systems such as lengthening of the plant growing. The climate of Lamto, which is included in that of West Africa, is influenced by the tropical Atlantic sea surface temperature [10-12] and the El Nino-Southern Oscillation (ENSO) [13-15]. These ocean surface conditions associated with the atmospheric circulation influence the seasonal migration of the intertropical convergence zone (ITCZ) marked by the monsoon shift between two equilibrium positions at $5^{\circ} \mathrm{N}$ and $10^{\circ} \mathrm{N}$ [16]. 
This last mechanism modulates the rainfall regime and induces a strong contrast between Sahel and Guinean regions.

Lamto region plays an important role at the local and regional scale when considering the biodiversity and the socioeconomic aspects. This role is essential in the water, carbon, and energy exchanges between soil and atmosphere. Foley et al. [17] showed that terrestrial ecosystems could affect the climate, particularly through the vegetation and soils. Various authors [18-20] also studied the relationship between the vegetation and the climate, and provided scientific evidences of the impact of vegetation dynamics on the climate at different spatial and temporal scales. The vegetation recycles locally moisture through evapotranspiration, which is an essential component of the hydrological cycle and determines water vapor transfers [21]. In addition, a change in meteorological and hydrological variables affects the functioning and the structure of the terrestrial ecosystem and the plants phenology. Furthermore, Moorcroft [20] showed that these interactions appear at short time scales when carbon, water, and energy exchanges are considered and they involve an ecosystem modification for large time scales.

The Lamto region has $80 \%$ of moist savanna and $20 \%$ of forest. The consequences that could involve deforestation and bush-fire occurrences on its climate require particular attention and assessment. For example, Manzi [22] and Dubreuil et al. [23] show that the impact of human activities (deforestation) on climate results in a decrease in evapotranspiration due to increased albedo, reduced roughness, and leaf area. Such decrease also causes an increase in surface temperature. However, no prospective and diagnostic studies have been undertaken consequently about the climate of Lamto from 1983 up to today. This present work aims to update the studies about the climate variability at Lamto and its impacts on the vegetation and water resources over a 50 -year period, from 1962 to 2011, using an empirical method based on the rainfall-temperature relationship defined by Moral [2]. This relation is not a simple proportionality relationship but the rainfall is a quadratic function of temperature. These two variables are measured at the Geophysical Station of Lamto. The 1962-2011 time series is divided into five decades (19621971, 1972-1981, 1982-1991, 1992-2001, and 2002-2011). The geographical setting and the climate variables are briefly described in Section 2. Section 3 gives an evaluation of the composite index of Moral and the rainfall variability at different timescales. Section 4 outlines the interactions between the African Monsoon and the local climate variables, whereas the combined analysis of climate-vegetation is undertaken in Section 5. Finally, discussions and perspectives at a regional scale are provided in the Section 6.

\section{Data and Methods}

Lamto $\left(5.02^{\circ} \mathrm{W} ; 6.13^{\circ} \mathrm{N}\right)$ is located within the "V" Baoule region of Côte d'Ivoire (Figure $1(\mathrm{a})$ ). It is surrounded by forest and hills and borders the southern rainforest. It covers an area of $27 \mathrm{~km}^{2}$ comprising $80 \%$ of moist savanna and $20 \%$ of forest. These characteristics make Lamto not belonging to the northern Sudanese savanna, but to an intermediate vegetation type called Guinean savanna. Four

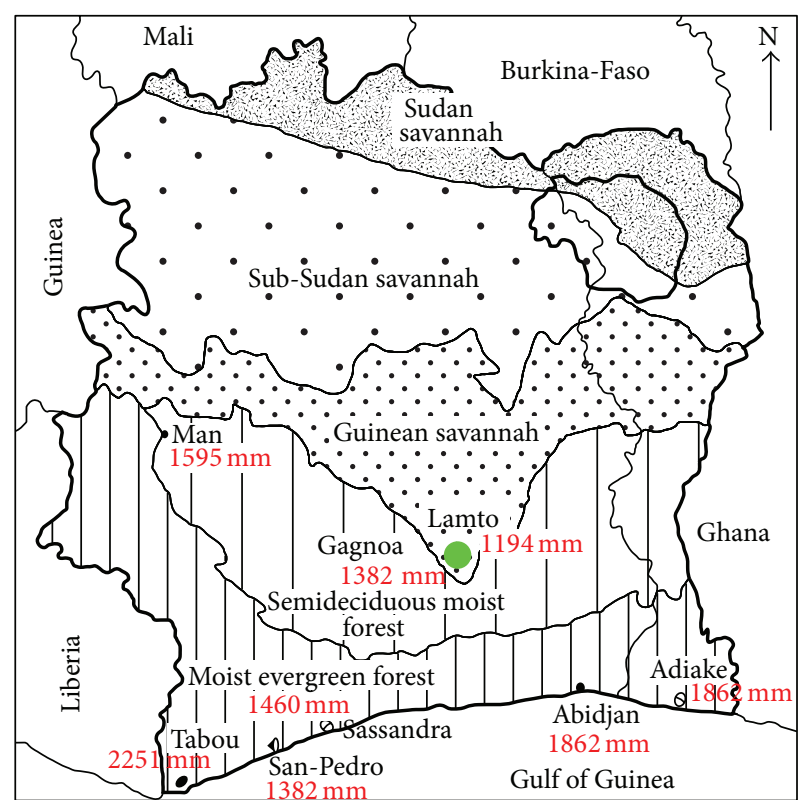

(a)

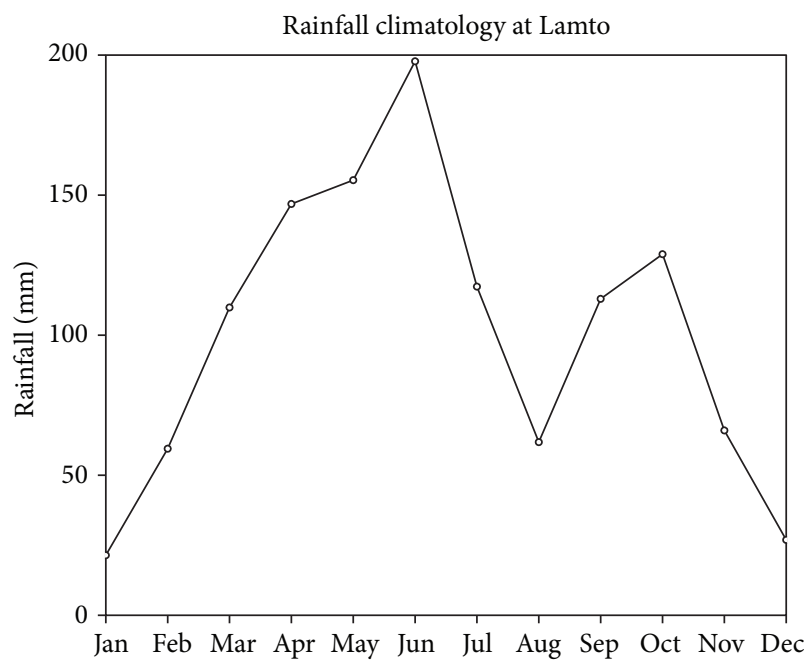

(b)

FIGURE 1: (a) Localization of the region of Lamto $\left(5.02^{\circ} \mathrm{W}-6.13^{\circ} \mathrm{N}\right)$ represented by the green area. Numbers in red are the mean annual rainfall (1962-1997) of some synoptic stations (Adapted from Guillamet et Adjanohoun [24]). (b) Mean seasonal cycle of the rainfall at Lamto during 1962-2011.

seasons characterize the climate of Lamto [25]: a long dry season occurring in December-February, a long wet season during March-July, a short dry season in August, and a short wet season in September-November (Figure 1(b)). The mean annual rainfall amount $(\sim 1212 \mathrm{~mm})$ is less than that of the neighboring synoptic stations mainly located in the southern rainforest or at the same latitude, as, for instance, Gagnoa where it reaches $1382 \mathrm{~mm}$. Several variables (e.g., rainfall, temperature, sunshine, etc.) that influence the climate are recorded daily at Lamto. The daily database covers 50 years, from 1962 to 2011. Among these variables, only rainfall and temperature are used in this work. They represent weather 
parameters that show the climate variability in West Africa [3]. In the following sections, the daily variables are averaged to obtain monthly dataset.

The composite index [2] based on the rainfall-temperature relationship is used to characterize climate type at Lamto. Moral [2] showed that the rainfall-temperature is not a simple proportionality relationship. He supposed that evaporation, which indicates the water requirements, does not vary as temperature. Then, he supposed that the rainfall efficiency is a quadratic function of temperature. Equation (1) summarizes this empirical relationship in which $P_{s}$ is the rainfall threshold between wet and dry seasons. $\bar{T}$ represents the mean annual temperature calculated from the period considered. Then, an annual pluviothermal index $\left(I_{a}\right)$ is calculated following (2). In this last relation, $P_{m}$ and $\bar{T}$ are the mean annual rainfall and temperature, respectively

$$
\begin{gathered}
P_{s}=\bar{T}^{2}-10 \bar{T}+200, \\
I_{a}=\frac{P_{m}}{\bar{T}^{2}-10 \bar{T}+200}=\frac{P_{m}}{P_{s}},
\end{gathered}
$$

with $P_{m}=(1 / n) \sum_{i=1}^{n} P_{i}$, where $n$ is the total number of years and $P_{i}$ the total rainfall in a year, and $\bar{T}=(1 / n) \sum_{i=1}^{n} T_{i}$, where $n$ is the total number of years and $T_{i}$, the mean temperature in a year. A value of $I_{a}=1$ represents the limit between wet tropical area and dry tropical area in West Africa. Different ranges of this pluviothermal index illustrate the localization of the given region. (A classification of different areas in Africa using the annual pluviothermal index is given in the work of Moral [2]. For a desert area, $I_{a} \leq 0.25$. For a subdesert area, $0.25<I_{a} \leq 0.5$. For an arid area, $0.5<I_{a} \leq 1$. For a subhumid area, $1<I_{a} \leq 2$. For a humid area, $2<I_{a} \leq 3$. For a rainy area, $I_{a}>3$.) $I_{a}$ could also be evaluated for a given year if the calculation is made yearly. In this case, $\bar{T}$ is the mean annual temperature and $P_{m}$ is the annual rainfall amount.

Four months categories, respectively, noted by rainy month (r), wet month (w), dry month (d), and arid month (a) are considered to define the annual cycle. The rainfall threshold that characterizes each type is given by the following empirical equations (3)-(5):

(i) rainy month/wet month:

$$
P_{s}=\frac{T^{2}}{10}+T+30
$$

(ii) wet month/dry month:

$$
P_{s}=\frac{T^{2}}{10}-T+20 ;
$$

(iii) dry month/arid month:

$$
P_{s}=\frac{T^{2}}{20}-T+10 .
$$

For example, a given month with a temperature of about $30^{\circ} \mathrm{C}$ could be included in the rainy month category if $P_{s} \geq 150 \mathrm{~mm}$, or in the wet month category if $80 \mathrm{~mm} \leq P_{s}<150 \mathrm{~mm}$, or in the dry month category if $25 \mathrm{~mm} \leq P_{s}<80 \mathrm{~mm}$, or finally in the arid month category if $P_{s}<25 \mathrm{~mm}$.

The mean atmospheric level reached by the monsoon flow and the associated mean atmospheric depth are depicted by using the monthly meridional wind field from $1000 \mathrm{hPa}$ to $700 \mathrm{hPa}$. This variable is extracted from the National Center for Environmental Prediction-National Center for Atmospheric Research (NCEP-NCAR) reanalysis [26] for the same period as that of the rainfall data. Monthly meridional wind data are reported on a $2.5^{\circ} \times 2.5^{\circ}$ grid.

Potential evapotranspiration (PE) is also used to study the interaction between the vegetation and the climate at Lamto. $\mathrm{PE}$ is calculated through (6) [27] during 1969 and 2001-2011 periods, instead of (1) the Penman-Monteith method [28] that is physically reasonable [29] but needs some parameters not recorded at Lamto and (2) the thornthwaite [30] method, which overestimates the impact of surface temperature on evaporation and leads to an unrealistic increase in drought frequency $[29,31,32]$. However, no values of PE are available between 1969 and 2001. The PE measurements stopped in the earlier 1969 and are continuously recorded from 2001 up to now

$$
\begin{aligned}
\mathrm{PE}= & {\left[0.4 \frac{t}{t+15}\right]\left[\left(0.62 \frac{h}{H}+0.18\right) I_{g A}+50\right] } \\
& \times\left[1+\frac{50-U}{70}\right],
\end{aligned}
$$

where PE is in mm, $t$ is temperature in ${ }^{\circ} \mathrm{C}, I_{g A}$ is the energy of solar radiation (in $\mathrm{cal} / \mathrm{cm}^{2} /$ day) that reaches the ground, and $h$ and $H$ are in hour. $H$ is the length of the day from sunrise to sunset and $h$ is the length of insolation. The factor $(50-U) / 70$ is taken into account only if the relative humidity $U$ is less than $50 \%$. As $U$ is higher than $50 \%$ at Lamto, this factor is neglected.

\section{Climate Variability at Lamto}

Figure 2 shows the interannual variability of $I_{a}$ and the limits $(\sim 1$ and $\sim 2)$ of this index for which Lamto could be localized in the arid, subhumid, or humid region. The interannual variability of the rainfall-standardized anomalies is also plotted. This last variable shows a good agreement with $I_{a}$, implying that one of these parameters (e.g., standardized anomaly or $I_{a}$ ) could be used to study the rainfall variability at Lamto. However, $I_{a}$ has the advantage to allow classifying Lamto in one of the climate areas; this constitutes one of the main objectives of this present work.

Most of the years have $I_{a}$ values ranged between 1 and 2 . That is in agreement with the results found in the decadal calculations. Nine years (1962, 1963, 1966, 1968, 1979, 1988, 1989, 2007, and 2010) allow including Lamto within the humid region (e.g., $I_{a}>2$ ) even if it is generally localized in the subhumid area when looking at the remaining 41 years for which $I_{a} \leq 2$. The years with $I_{a}>2$ represent abnormal periods during which the rainfall amount was exceptionally high, particularly the most wet year $1968\left(I_{a} \sim 2.55\right)$. The low 


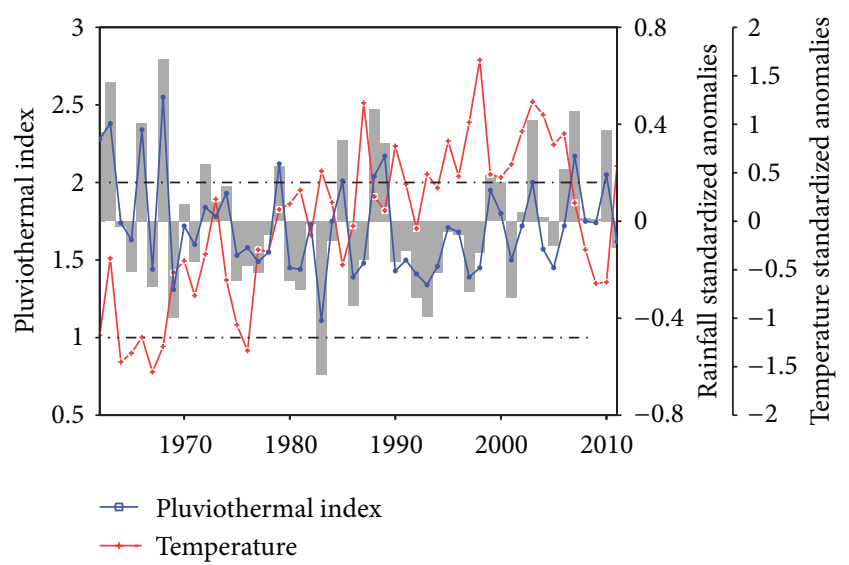

Figure 2: Annual pluviothermal index (blue curve), the annual standardized anomalies of rainfall (histogram) and of temperature (red curve) calculated as departures to the climatology during 19622011. Horizontal dashed lines represent the limits for which Lamto could be localized in the arid $\left(I_{a}<1\right)$, subhumid $\left(1<I_{a} \leq 2\right)$, or humid $\left(2<I_{a} \leq 3\right)$ region.

values of $I_{a}$ are found in $1969(\sim 1.30)$ and $1983(\sim 1.11)$. Kouadio et al. [3] noted that the years 1968 and 1983 experienced, respectively, flood and severe drought phenomena in West Africa. The climate conditions during these two years are known to be related to the abnormal heating of the tropical Atlantic Ocean (for 1968) and to the El-Niño (for 1983) [10]. The flood during 1968 was associated with positive SST anomalies $\left(>1.5^{\circ} \mathrm{C}\right)$ trapped along the equator in the core of Gulf of Guinea. That warm event followed a relaxation of the western equatorial wind [10]. In the case of drought in 1983, the trades were very weak in the central part of the equatorial Pacific from mid-1982 to mid-1983, which corresponded to the mature phase of the El Niño. At the same time, the westerly wind at $200 \mathrm{hPa}$ increased while the easterly winds at $850 \mathrm{hPa}$ were stronger than normal above the equatorial Atlantic. This climate conditions persisted in July 1983 and encouraged the cooling of the tropical Atlantic Ocean due to strong trades [33]. This abnormal situation implied a decrease in convective activity with a drought over West Africa.

Low fluctuations of $I_{a}$ observed during 1969-1978 and 1990-1998 periods could be related to rainfall deficit. For instance, Le Barbé et al. [34] showed that the rainfall deficit occurring during 1969-1978 caused drought and famine in the Sahel. This deficit also extended to the West African coastal region. Many authors [34-38] also discussed the rainfall deficit observed during 1990-1994, which is included in the 1990-1998 dry period. They found that the socioeconomic impact of this last climate situation was similar to that of 1969-1978.

The 1962-2011 period is divided into five decades that are 1962-1971, 1972-1981, 1982-1991, 1992-2001, and 20022011 since the West African rainfall is characterized by strong variability, both at decadal and interannual scales [39]. This subdivision allows (i) understanding the climate variability of this region and (ii) looking at if the decadal changes are related to recent climate variations. Table 1 presents some of the variables $\left(I_{a}\right.$, month category) performed in Section 2 .
The mean pluviothermal index $\left(I_{a}\right)$ during the entire 19622011 period is equal to 1.71 . That could imply the localization of Lamto within the subhumid area. When considering each decade, the same conclusion could be made. The higher value of $I_{a}(\sim 1.90)$ in 1962-1971 shows that this decade was the most wet during the studied period. It indicates that Lamto was very close to humid region because this index is practically equal to 2 . Such result is already mentioned by some authors for the Sahelian region [40] and for the entire West African region [6]. The lowest value $(\sim 1.57)$ of $I_{a}$ in 1992-2001 is consistent with a decrease in rainfall in West Africa during this period [3, 41, 42]. The relative difference for both variables between each decade and the entire period corroborates these findings. The highest values for rainfall are found during the 1962-1971 ( +5.78\%) and 2001-2012 ( +5.73\%) decades. These values illustrate an excess of rainfall if one considers the entire period. The other decades exhibit negative relative difference with the lowest one during 1992-2001 ( -5.67\%). In the case of the temperature, the progressive increase from the lowest value ( - 2.54\%) in 1962-1971 to the highest one $(\sim+1.57 \%)$ in 1992-2001 indicates warming. After the 19922001 decade, the relative difference decreases even remaining positive. The local interdecadal changes of rainfall show many similarities to the Northern African monsoon index shown in Figure 2a of Zhou et al. [43] and in Figure 9a of Zhang and Zhou [44]. These results are obvious since the increase (resp., decrease) of rainfall is related to cooling (resp., a warming) at Lamto. Such behavior of the rainfall and temperature during these decades could be related to human activities that locally contribute to this modulation. For example, a report of FAO [45] and Bertrand [46] argued that the human activities, which consist of deforestation and bushfire, are responsible for the rainfall decrease.

Global monthly classification during the 1962-2011 period (see Table 1) indicates three rainy months (AprilJune), four wetter months (March, July, and SeptemberOctober), and five dry months (November-February and August). No arid month is found if the entire period is considered. When looking on each decade, June, March, and February remain, respectively, rainy, wet, and dry months. The other months show a change in their category, depending on the local climate conditions during the decade. The number of rainy months decreases from the first decade $(\sim 5)$ to the last decade $(\sim 3)$ when the number of dry months rises from 2 to 4 . The increase in dry months is due to August, which has begun drier during the last two decades.

Students $t$-test of the mean annual rainfall (Table 2) and temperature (Table 3 ) is shown for a given decade and the following decades or the entire period. Non-significant differences are found for the mean annual rainfall for most of decades. That illustrates a constant rainfall regime in this region even if some years could be abnormally humid or dry for a given decade. The present remark will be discussed in the following paragraph. An interesting and significant negative difference is found between the 1992-2001 and 20022011 decades. The negative value of Student $t$-test shows that the rainfall amount during 1992-2001 was lower than that of 2002-2011. That is consistent with lower values of $I_{a}$ during 1992-2001 and could be related to rainfall deficit 
TABLE 1: Pluviothermal index $\left(I_{a}\right)$, month categories, and the relative difference between each decade and the entire period for both variables.

\begin{tabular}{|c|c|c|c|c|c|c|c|c|c|c|c|c|c|c|c|}
\hline \multirow{2}{*}{ Period } & \multirow{2}{*}{$\begin{array}{l}\text { Relative error }(\%) \text { of } P_{m} \\
\text { versus } 1962-2011\end{array}$} & \multirow{2}{*}{$\begin{array}{l}\text { Relative error (\%) of } T \\
\text { versus 1962-2011 }\end{array}$} & \multirow{2}{*}{$I_{a}$} & \multicolumn{12}{|c|}{ Month category } \\
\hline & & & & $\mathrm{J}$ & $\mathrm{F}$ & M & $\mathrm{A}$ & $\mathrm{M}$ & $\mathrm{J}$ & $\mathrm{J}$ & A & S & $\mathrm{O}$ & $\mathrm{N}$ & $\mathrm{D}$ \\
\hline $1962-1971$ & +5.78 & -2.54 & 1.90 & $\mathrm{a}$ & $\mathrm{d}$ & $\mathrm{w}$ & $\mathrm{r}$ & $\mathrm{r}$ & $\mathrm{r}$ & $\mathrm{r}$ & $\mathrm{w}$ & $\mathrm{r}$ & $\mathrm{w}$ & $\mathrm{w}$ & $\overline{\mathrm{d}}$ \\
\hline $1972-1981$ & -3.76 & -0.75 & 1.67 & $\mathrm{~d}$ & $\mathrm{~d}$ & $\mathrm{w}$ & $\mathrm{r}$ & $\mathrm{r}$ & $\mathrm{r}$ & $\mathrm{w}$ & $\mathrm{d}$ & $\mathrm{w}$ & $\mathrm{w}$ & $\mathrm{d}$ & $\mathrm{d}$ \\
\hline 1982-1991 & -2.07 & +0.67 & 1.66 & $\mathrm{a}$ & $\mathrm{d}$ & $\mathrm{w}$ & $\mathrm{r}$ & $\mathrm{r}$ & $\mathrm{r}$ & $\mathrm{w}$ & $\mathrm{w}$ & $\mathrm{w}$ & $\mathrm{w}$ & $\mathrm{d}$ & d \\
\hline 1992-2001 & -5.67 & +1.57 & 1.57 & $\mathrm{~d}$ & $\mathrm{~d}$ & $\mathrm{w}$ & $\mathrm{w}$ & $\mathrm{w}$ & $\mathrm{r}$ & $\mathrm{r}$ & $\mathrm{d}$ & $\mathrm{w}$ & $\mathrm{w}$ & $\mathrm{d}$ & $\mathrm{a}$ \\
\hline $2002-2011$ & +5.73 & +1.04 & 1.78 & $\mathrm{~d}$ & $\mathrm{~d}$ & $\mathrm{w}$ & $\mathrm{w}$ & $\mathrm{r}$ & $\mathrm{r}$ & $\mathrm{w}$ & $\mathrm{d}$ & $\mathrm{w}$ & $\mathrm{r}$ & $\mathrm{w}$ & d \\
\hline $1962-2011$ & & & 1.71 & $\mathrm{~d}$ & d & $\mathrm{w}$ & $\mathrm{r}$ & $\mathrm{r}$ & $\mathrm{r}$ & $\mathrm{w}$ & $\mathrm{d}$ & $\mathrm{w}$ & $\mathrm{w}$ & $\mathrm{d}$ & d \\
\hline
\end{tabular}

TABLE 2: Comparisons between the mean annual rainfall of a given decade and the following decades or the entire period by using Student's $t$-test.

\begin{tabular}{lccccrc}
\hline Decades & & \multicolumn{3}{c}{ Decades } \\
& $1962-1971$ & $1972-1981$ & $1982-1991$ & $1992-2001$ & & \\
$1962-1971$ & 0 & & & & \\
$1972-1981$ & 1.07 & 0 & 0 & & \\
$1982-1991$ & 0.80 & -0.22 & 0.51 & 0 & \\
$1992-2001$ & 1.32 & 0.33 & -1.09 & -2.02 & 011 \\
$2002-2011$ & 0.01 & -1.57 & -0.43 & -1.08 & 0.87 \\
$1962-2011$ & 0.79 & 0.79 & & & 0 \\
\hline
\end{tabular}

Bold values of the value of student's $t$-test are significant at the $95 \%$ confidence level.

TABLE 3: Comparisons between the mean annual temperature of a given decade and the following decades or the entire period by using the Student's $t$-test.

\begin{tabular}{|c|c|c|c|c|c|c|}
\hline \multirow{2}{*}{ Decades } & \multicolumn{6}{|c|}{ Decades } \\
\hline & $1962-1971$ & $1972-1981$ & 1982-1991 & $1992-2001$ & 2002-2011 & 1962-2011 \\
\hline $1962-1971$ & 0 & & & & & \\
\hline $1972-1981$ & -3.15 & 0 & & & & \\
\hline 1982-1991 & -6.28 & -2.54 & 0 & & & \\
\hline $1992-2001$ & -8.00 & -4.09 & -1.70 & 0 & & \\
\hline $2002-2011$ & -5.42 & -2.54 & -0.64 & 0.83 & 0 & \\
\hline $1962-2011$ & -3.97 & -3.97 & 1.05 & 2.44 & 1.52 & 0 \\
\hline
\end{tabular}

Bold values of the value of Student's $t$-test are significant at the $95 \%$ confidence level.

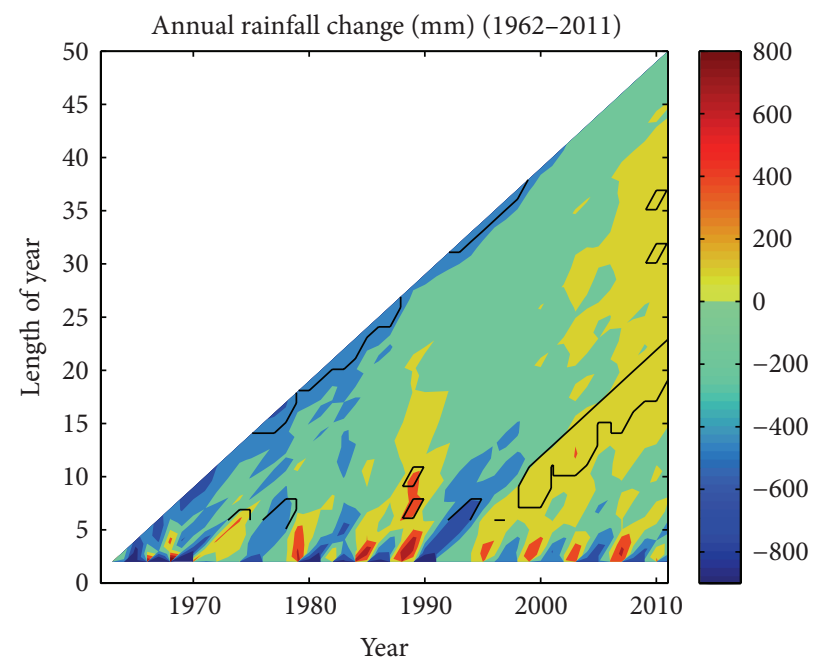

(a)

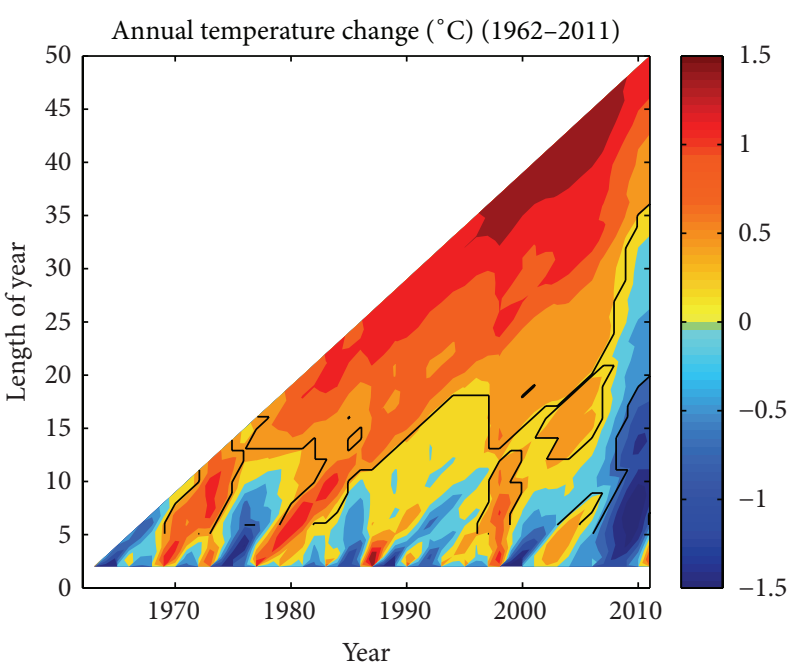

(b)

Figure 3: (a) Change of rainfall (in mm) and (b) air temperature $\left({ }^{\circ} \mathrm{C}\right)$ from 1962 to 2011 as a function of length of time segment and ending year of calculation; the black contours provide the confidence ranking Students $t$-test. 
(see Figure 2) whereas Student $t$-test for 2002-2011 implies an increase in rainfall. In the case of the temperature (see Table 3), the first two decades (1962-1971 and 1972-1981) give a significant negative value in the following decades. This indicates that they are the coolest periods of the time series. However, the significant positive value found for the 19922001 decade is related to abnormal warming that is already discussed in the previous paragraphs.

A complementary analysis of the interannual study is now provided by using a statistical diagnostic based on the linear regression by the least squares fit [47]. This method is used to objectively detect one or more tendency breaks in the rainfall and temperature time series and when they occur. Figure 3 displays every possible cumulative rainfall (Figure 3(a)) and temperature (Figure 3(b)) change and the corresponding confidence Students $t$-test during each time segment from a 2-year to a 50-year period (e.g., the total length of the available time series). The cumulative changes (in $\mathrm{mm}$ for rainfall and in ${ }^{\circ} \mathrm{C}$ for temperature) are obtained when multiplying the coefficient of the linear trends by the length of the time series. For example, if the rainfall is considered (see Figure 3(a)), the value plotted at point $x=2011, y=20$ corresponds to the 20 -year change $(\sim+170 \mathrm{~mm})$ computed during the time segment 1992-2011. It is evident that time segments of a few years or shorter can exhibit either high rainfall excess or rainfall deficit, while trends for longer segments are quite weak compared to those present in shorter segments. Thus, an alternation of negative and positive trends occurs if all lengths of segment in ordinate are taken into account. This means that no long-term trend break exists for rainfall. However, a positive significant trend at the $95 \%$ confidence level occurs after 2002 and remains permanent up to 2011. That is consistent with the increase in rainfall noted from the 19922001 to 2002-2011 decades (see Figure 2). In the case of the temperature (see Figure 3(b)), a long-term trend break occurs for a length of segment greater than 30 years. A negative trend exists from 1962 to 2008, while, after 2008, no negative trend is observed any more. However, for a length of segment greater than 10 years, a negative and significant temperature trend $\left(\sim-1^{\circ} \mathrm{C}\right)$ occurs from 2005 to 2011 . Such trend agrees well with the increase in rainfall during this period.

\section{Influence of the West African Monsoon}

Burpee [48] and Dhonneur [49] provided a diagram of the meridional structure of the atmosphere over West Africa and the associated five climatic zones, respectively, noted by A, B, $\mathrm{C} 1, \mathrm{C} 2$, and D (Figure 4) according to the seasonal migration of the intertropical convergence zone (ITCZ). When looking at this diagram, Côte d'Ivoire is located both into the zones D and C2. Particularly, Lamto is included into the zone D that (1) borders the tropical Atlantic Ocean and (2) is most influenced by moisture coming from the Ocean. The impact of the monsoon on this zone depends on the months during the seasonal cycle and could vary for particular years. This section outlines the impact of the West African monsoon on the climate variability at Lamto. Such study is undertaken by using the meridional wind from the NCEP-NCAR reanalysis data [26]. At the point closed to Lamto coordinates, the monthly atmospheric level reached by the monsoon flow coming from the ocean (South to North) is determined when the meridional wind direction changes from positive to negative value. The maximum level is fixed at $700 \mathrm{hPa}$ since it is currently used to study easterly waves over West Africa [50, 51].

Figure 5 shows the climatology of the mean atmospheric level determined during 1962-2011. The lowest level values ( $860-890 \mathrm{hPa}$ ) are found from November to February. These months correspond to arid and dry periods (see Table 1). Two modes characterize the seasonal cycle. The first mode $(\sim 795 \mathrm{hPa})$ is observed during May-June when the ITCZ is localized at the littoral coast. This period is related to the great rainfall season at Lamto and the littoral regions of Côte d'Ivoire [3]. The monsoon "jump" [16] occurs from June to July, and the mean atmospheric level reaches approximately $790 \mathrm{hPa}$ in August that represents the second mode. During this last period, the ITCZ is at its most northward position over the continent. Such increase in the mean atmospheric level allows the monsoon flow penetrating far into the land.

Figure 6(a) illustrates the interannual variability of the mean atmospheric depth of the monsoon flow at Lamto. This depth is calculated from the difference between the ground $(\sim 1000 \mathrm{hPa})$ and the high atmospheric level reached by the flow each month. The mean depth during the entire period is approximately $180 \mathrm{hPa}$. The mean depth ranges between $100 \mathrm{hPa}$ and $200 \mathrm{hPa}$ (e.g., 900 to $800 \mathrm{hPa}$ for the levels) for almost all years except those of the first decade (19621971) and the 2007-2009 period where it reaches $300 \mathrm{hPa}$. An interesting observation is that, when the depth is greater than $250 \mathrm{hPa}$ (that means an atmospheric level greater than $750 \mathrm{hPa}$ ), the pluviothermal index is also greater than 2 (see Figure 2). Such mean depth threshold could be used in association with the pluviothermal index to yearly classify a region in a climate type.

Figure 6(b) shows the standardized anomalies of the mean depth and the regression linear fits during all decades. An increase in the mean depth during 1990-2001 and 20022011 is coincident with the rainfall increase in these decades. The correlation $(\sim 0.40)$ between Ia and the annual standardized anomalies of the mean depth is significant at the $95 \%$ confident level with Student $t$-test. It means that a high depth is related to a high rainfall amount. Such situation particularly occurs when Lamto is classified as a humid region. This could be explained by the fact that more humidity comes from the tropical Atlantic Ocean to the studied region and contributes to the rainfall increase. The periods for which standardized anomalies of the mean depth are closed or little to zero (e.g., a mean depth ranged between $100 \mathrm{hPa}$ and $200 \mathrm{hPa}$ ) correspond to less penetration of the monsoon flow. This situation allows including Lamto into a subhumid or arid area, depending on the value of the pluviothermal index.

\section{Interaction with the Vegetation at Lamto}

Monthly variation of the potential evapotranspiration (hereafter PE) and the rainfall are analyzed during the year 1969 and the 2001-2011 period (Figure 7). These years represent periods during which sunshine, air temperature, and the relative humidity measurements are recorded at Lamto. 


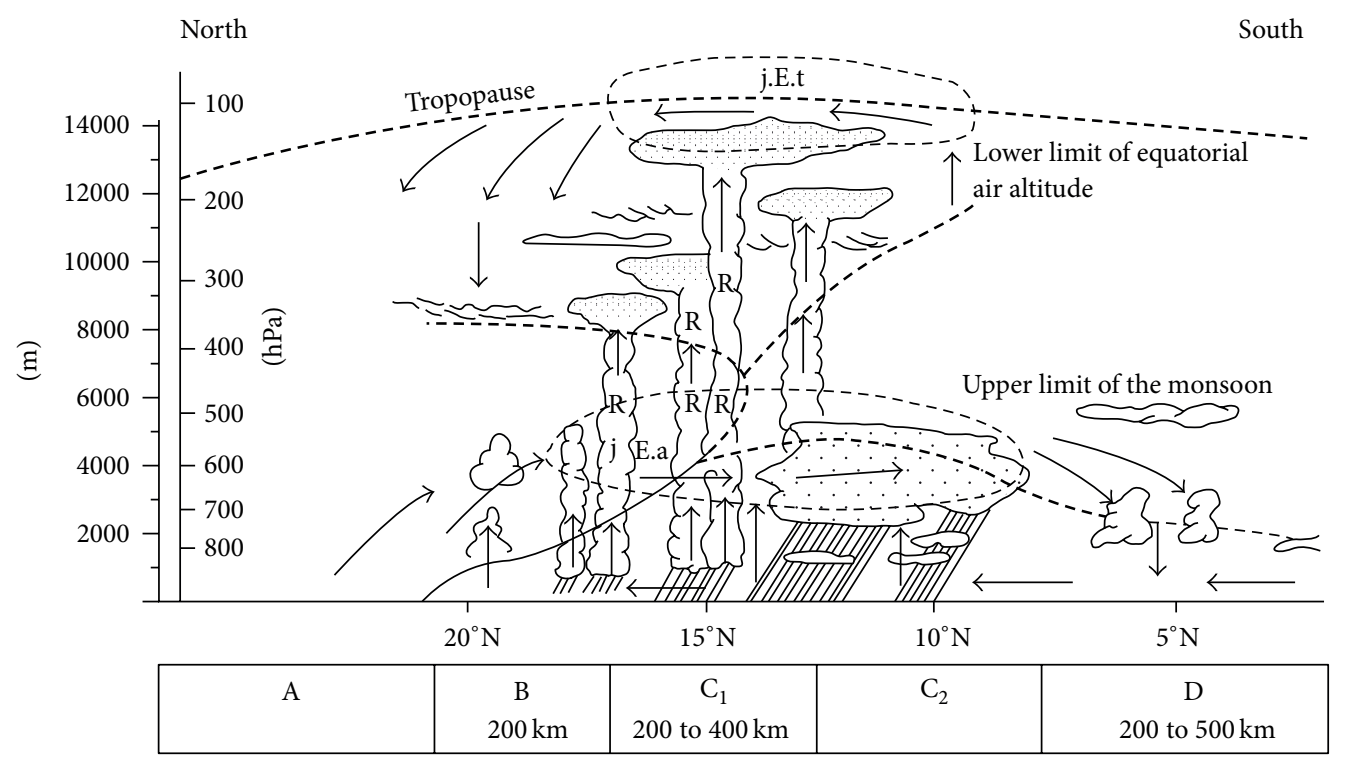

FIGURE 4: Diagram of the meridional structure of the atmosphere in August over West Africa (adapted to Burpee [48] and Dhonneur [49]). The arrows show flows and in particular convection or subsidence of air mass.

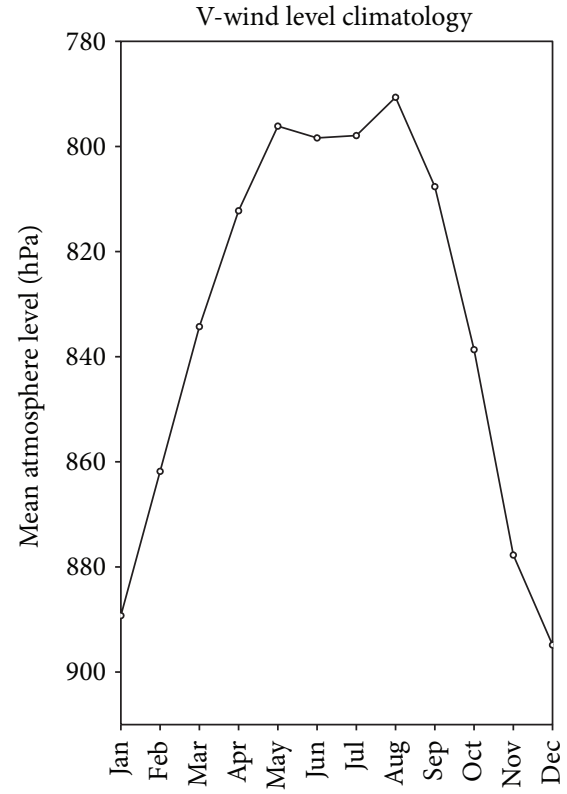

FIGURE 5: Climatology of the mean atmospheric level reached by the monsoon flow coming from the ocean. Levels are obtained at $6^{\circ} \mathrm{N} ; 5^{\circ} \mathrm{W}$ for the level at which the direction of the meridional wind changes from positive to negative value.

Surprisingly, the year 1969 and the 2001-2011 period represent, respectively, a rainfall deficit and an increase in rainfall (see Figure 2). Note that PE illustrates the water requirements of the climate since it influences the climate at global scale [52]. PE represents the sum of the direct evaporation from moist soils of various free ground waters and of the water vapor flux coming from the plant transpirations.

PE values are higher in 1969 than in 2001-2011 period, when the rainfall shows an opposite evolution. For instance, the annual PE value reaches $1380 \mathrm{~mm}$ in 1969 when it does not exceed $800 \mathrm{~mm}$ from 2001 to 2011. The rainfall amount is, respectively, $902 \mathrm{~mm}$ in 1969 and greater than $1000 \mathrm{~mm}$ during 2001-2011. The difference between annual PE and rainfall is positive in $1969(\sim 477.4 \mathrm{~mm})$ and negative during 2001-2011 (<-376 mm). Such calculation could explain a rainfall deficit in 1969 and rainfall excess in 2001-2011. The increase of rainfall during 2001-2011 could be related to the development of the vegetation, which is under an ecological protection for many years. It is also consistent with that of the whole North African monsoon precipitation $[43,44]$ and could represent a local manifestation of it. The low values of $\mathrm{PE}$ in the 2001-2011 period could result in the reduction of the turbulent exchange between the surface and the lower layers of the atmosphere. This could be also induced by the rainfall increase in the same period. Although the vegetation is under an ecological protection, the intensive deforestation since the first decade caused radical changes in Lamto environment. These human activities concern the expansion of crops and the development of extensive pastures. Such remark agrees with Freitas [53] who showed that the conversion of a tropical humid forest into pasture induces a reduction of $70-80 \%$ of the initial content of the biomass, which is necessary to $\mathrm{PE}$ increase. Another factor that could exacerbate the PE decrease is the surface roughness (not shown). The size of the vegetation at Lamto has not significantly increased since 1969s. This is due to the frequency of bushfires (Figure 8) and pasture development. These cause a decrease in the friction force and imply a reduction of the PE. That is concordant with Sud et al. [54] who showed that the vegetation height could affect the water vapor transport and the rainfall distribution.

\section{Conclusion}

This work aims to study the climate variability in West Africa and its impact on the vegetation at Lamto $\left(6.13^{\circ} \mathrm{N}, 5.02^{\circ} \mathrm{W}\right)$ 


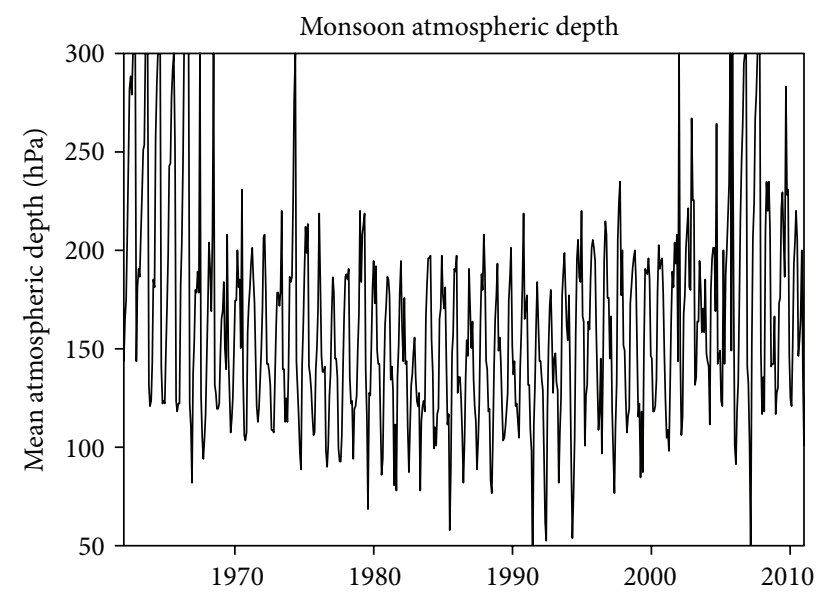

(a)

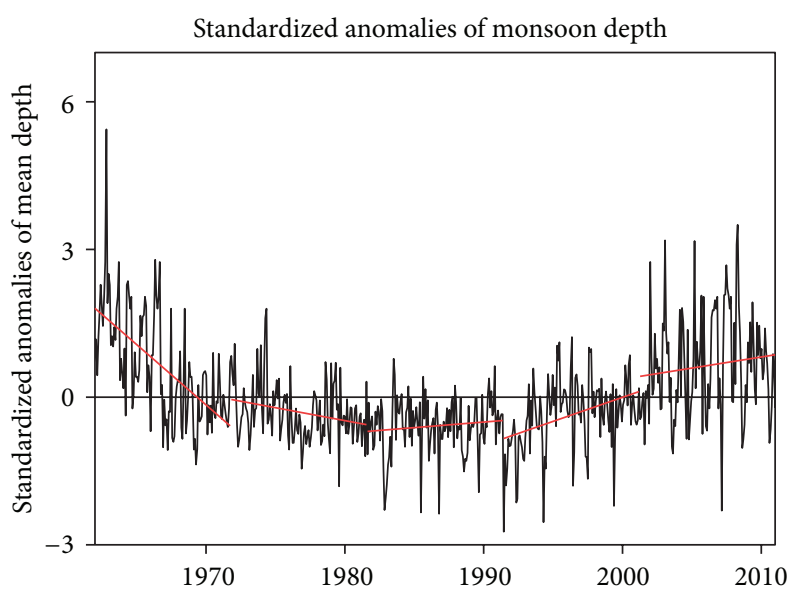

(b)

Figure 6: (a) Mean atmospheric depth of the monsoon flow at Lamto calculated from the difference between $1000 \mathrm{hPa}$ and the atmospheric level reached by the monsoon flow coming from the ocean. (b) Standardized anomalies of the atmospheric depth of the monsoon calculated from (a). Linear regression fits (red) of the five decades (1962-1971, 1972-1981, 1982-1991, 1992-2001 and 2002-2011) are plotted.

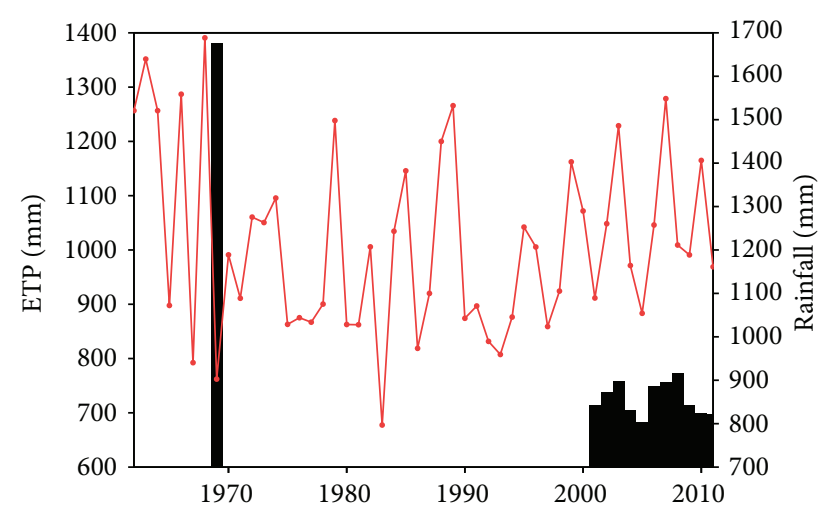

Figure 7: Annual evolution of PE (black bars) and rainfall (red line) during 1962-2011.

localized in Côte d'Ivoire. To undertake this work, a set of monthly 50-year data during the 1962-2011 period is used. It concerns rainfall and temperature relationships, the mean depth of the monsoon flow coming from the tropical Atlantic Ocean, and the potential evapotranspiration.

The climate variability is studied by using an index $\left(I_{a}\right)$ based on a rainfall-temperature relationship defined by Moral [2]. A comparison between this index and the rainfallstandardized anomalies shows good agreement between these two variables. However, $I_{a}$ has an advantage to allow classifying Lamto into one of the climate regions, depending on the yearly value reached by this index. The interannual variability of $I_{a}$ indicates that nine years help to classify Lamto as a humid region. The climate conditions during the other years allow including Lamto into a subhumid region because the $I_{a}$ value ranged between 1 and 2 and even if a rainfall deficit is observed for some years. For example, the severe drought experienced in West Africa during $1983\left(I_{a} \sim\right.$ 1.11) is related to El-Niño occurrence [10]. This local change of rainfall shows many similarities to the Northern African monsoon index $[43,44]$.
A decadal scale analysis shows an increasing trend of rainfall during the 1962-1971 and 2002-2011 periods with the most one during the first decade. The other decades show a decreasing trend. Such behaviour of the rainfall is influenced by the category in which each month is classified. A complementary analysis of the interannual study is also provided by using a statistical diagnostic based on the linear regression by the least squares fit [47]. It shows that no long-term trend break exists for rainfall. However, a positive significant trend occurs after 2002 and remains permanent up to 2011. In the case of the temperature, a long-term 30year trend break exists. A negative significant trend $\left(\sim-1^{\circ} \mathrm{C}\right)$ occurs during 2005-2011 that agrees well with the rainfall increase during the last decade 2002-2011.

The impact of the West African monsoon on the climate variability at Lamto is also undertaken. It depends on the months during the annual cycle and could vary for particular years. The climatology of the atmospheric level reached by the monsoon flow shows that the lowest levels $(\sim 860-$ $890 \mathrm{hPa}$ ) are noted from November to February. A monsoon "jump" is observed from June to July, and the level reaches approximately $790 \mathrm{hPa}$ in August.

The interannual variability of the mean atmospheric depth of the monsoon flow at Lamto ranged between $100 \mathrm{hPa}$ and $200 \mathrm{hPa}$ ( $\sim 900$ to $800 \mathrm{hPa}$ for the levels) for almost all years even reaching $300 \mathrm{hPa}$ during the 1962-1971 and 20072009 periods. An interesting result is that the mean depth varies similarly with $I_{a}$.

The monthly variation of potential evapotranspiration highlights the relationship between the vegetation and the climate at Lamto. It shows that the recent increase in rainfall during 2001-2011 could be related to the development of the vegetation and is also consistent with that of the whole North African monsoon precipitation $[43,44]$.

The results of this paper show that it is possible, with long time series, to have significant information about (1) the climate classification and (2) the vegetation which impacts 


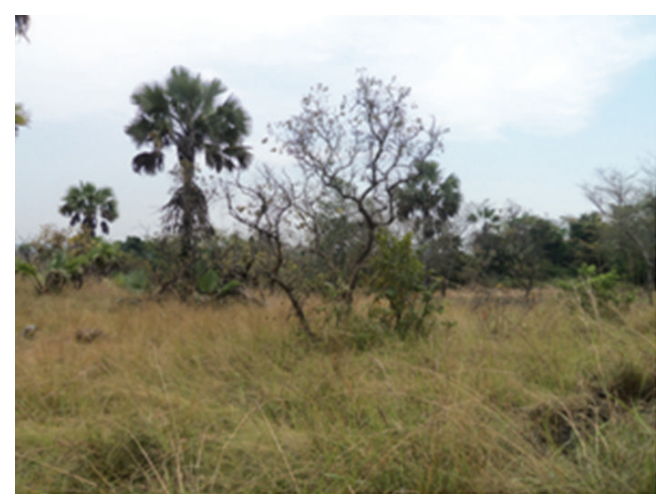

(a)

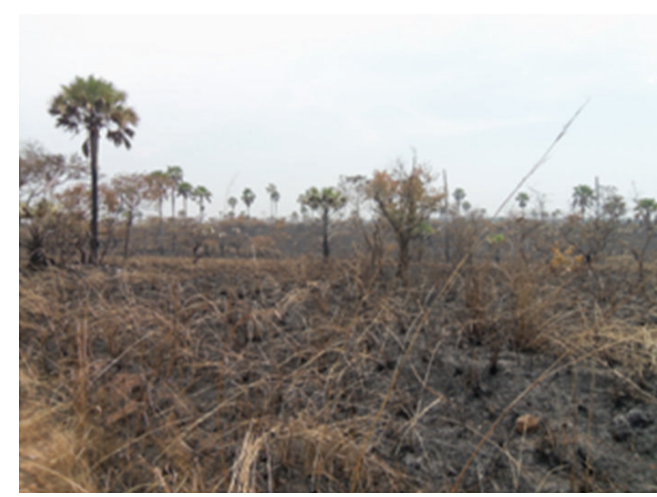

(b)

Figure 8: Overview of the vegetation at Lamto (a) before the bushfire in October 2011 and (b) after the bushfire in December 2011.

on the local climate. As only a local scale is considered in this work, the study can be extended at a regional scale in a context of climate change. Such study could be made with a regional climate model. It could be also a valuable tool for studying the impacts of the rainfall variability on the agricultural productions in the West African countries. For this kind of study, the Regional Climate Model-MAR [55] is a good candidate. This model is used at the Laboratory of Atmospheric Physics and Fluid Mechanics (LAPA-MF) at the University Felix Houphouët-Boigny of Cocody in Côte d'Ivoire. This model has already shown its ability to reproduce the atmospheric dynamics and the rainfall patterns in West Africa [56] and the major characteristics of the mesoscale convective disturbances [57]. That is one of the topics of the program Jeune Equipe Associée à l'IRD (JEAI) named Littoral, Oceanic and Climate Analysis at the North of the Gulf of Guinea (ALOC-GG) and financed by the French Institute of Research and Development (IRD).

\section{Conflict of Interests}

The authors declare that there is no conflict of interests regarding the publication of this paper.

\section{Acknowledgments}

This work is undertaken in the framework of the "Jeune Equipe Associée à l'IRD named Analyses Littorale, Océanique et Climatique au nord du Golfe de Guinée" (JEAI, ALOC-GG). The publication was made possible through support provided by the French "Institut de Recherche pour le DéveloppementDirection des programmes de Recherche et de la formation au Sud" (IRD-DPF). The authors thank the Geophysical Station of Lamto for its financial support. They also thank all the employees of Lamto who accepted to provide them the datasets used in this study. They are grateful to Mr. Patrick Donoghue for improving the English form of the paper. The authors also would like to thank the anonymous reviewers for their valuable comments and suggestions to improve the quality of the paper.

\section{References}

[1] F. Bagnouls and H. Gaussen, "Les climats biologiques et leur classification," Annales De Géographie, vol. 355, pp. 193-220, 1957.

[2] P. Moral, "Essai sur les régions pluviothermiques de l'Afrique de l'Ouest," Annales De Géographie, no. 400, pp. 660-686, 1964.

[3] K. Y. Kouadio, A. Aman, A. D. Ochou, K. E. Ali, and P. A. Assamoi, "Rainfall variability patterns in West Africa: case of Cote d'Ivoire and Ghana," Journal of Environmental Science and Engineering, vol. 5, pp. 1229-1238, 2011.

[4] E. Servat, J. E. Paturel, H. Lubès-Niel et al., "De différents aspects de la variabilité de la pluviométrie en Afrique de l'Ouest et Centrale non sahélienne," Journal of Water Science, vol. 12, no. 2, pp. 363-387, 1999.

[5] T. Brou, "Variabilité climatique, déforestation et dynamique agrodémographique en Côte d'Ivoire," Sécheresse, vol. 21, no. 1, pp. 1-6, 2010.

[6] S. E. Nicholson, "The nature of rainfall variability over Africa on time scales of decades to millenia," Global and Planetary Change, vol. 26, no. 1-3, pp. 137-158, 2000.

[7] C. Lecordier, Les peuplements de Carabiques (Coléoptères) dans la savane de Lamto (Côte d'Ivoire) [Ph.D. thesis], Public Laboratory Zoology, 1975.

[8] W. Köppen, "Das geographische system der klimate," in Handbuch Der Klimatologie, vol. 5, 1936.

[9] P. Forge, "Nouvelle approche de la définition des saisons climatiques de la région de Lamto (Côte d'Ivoire)," AnnaLe de L'Université d'Abidjan E, vol. 15, pp. 7-25, 1982.

[10] Y. K. Kouadio, D. A. Ochou, and J. Servain, “Tropical Atlantic and rainfall variability in Côte d'Ivoire," Geophysical Research Letters, vol. 30, no. 5, pp. 1-15, 2003.

[11] S. E. Nicholson, "Climatic and environmental change in Africa during the last two centuries," Climate Research, vol. 17, no. 2, pp. 123-144, 2001.

[12] H. Paeth and A. Hense, "SST versus climate change signals in West African rainfall: 20th-century variations and future projections," Climatic Change, vol. 65, no. 1-2, pp. 179-208, 2004.

[13] S. Janicot, V. Moron, and B. Fontaine, "Sahel droughts and ENSO dynamics," Geophysical Research Letters, vol. 23, no. 5, pp. 515-518, 1996.

[14] V. Moron, S. Bigot, and P. Roucou, "Rainfall variability in subequatorial America and Africa and relationships with the 
main sea-surface temperature modes (1951-1990)," International Journal of Climatology, vol. 15, no. 12, pp. 1297-1322, 1995.

[15] M. N. Ward, "Diagnosis and short-lead time prediction of summer rainfall in tropical North Africa at interannual and multidecadal timescales," Journal of Climate, vol. 11, no. 12, pp. 31673191, 1998.

[16] B. Sultan and S. Janicot, "Abrupt shift of the ITCZ over West Africa and intra-seasonal variability," Geophysical Research Letters, vol. 27, no. 20, pp. 3353-3356, 2000.

[17] A. J. Foley, M. H. Costa, C. Delire, N. Ramankutty, and P. Snyder, "Green surprise? How terrestrial ecosystems could affect earth's climate," Ecological Environment, vol. 1, pp. 38-44, 2003.

[18] N. Zeng, R. E. Dickinson, and X. Zeng, "Climatic impact of Amazon deforestation-a mechanistic model study," Journal of Climate, vol. 9, no. 4, pp. 859-883, 1996.

[19] R. A. Pielke Sr., R. Avissar, M. Raupach, A. J. Dolman, X. Zeng, and A. S. Denning, "Interactions between the atmosphere and terrestrial ecosystems: influence on weather and climate," Global Change Biology, vol. 4, no. 5, pp. 461-475, 1998.

[20] P. R. Moorcroft, "Recent advances in ecosystem-atmosphere interactions: an ecological perspective," Proceedings of the Royal Society B, vol. 270, no. 1521, pp. 1215-1227, 2003.

[21] B. Sultan, E. Servat, J. Maley, and G. Mahe, "Interrelations entre les forêts tropicales et la variabilité climatique: une synthèse des études récentes," Sécheresse, vol. 12, no. 4, pp. 1-9, 2001.

[22] A. Manzi, Introduction d'un schéma des transferts sol-végétationatmosphère dans un modèle de circulation générale et application à la simulation de la déforestation amazonienne [Ph.D. thesis], de l'Université de Toulouse, Toulouse, France, 1993, 93 TOU3 0111.

[23] V. Dubreuil, H. Quénol, V. Nedelec, J. F. Mallet, L. Durieux, and G. Maitelli, "Etude de l'impact du changement de l'occupation du sol sur les températures dans la région d’alta floresta, Brésil," Bulletin de la Société Géographique de Liège, vol. 51, pp. 79-90, 2008.

[24] J.-L. Guillaumet and E. Adjanohoun, "La végétation de la Côte d'Ivoire," in Le Milieu Naturel de La Côte d'Ivoire, pp. 157-266, O.R.S.T.O.M., Paris, France, 1971.

[25] J. Arbeille, Recherches biologiques et écologiques sur les blattes de la région de Lamto (Côte d'Ivoire) [Thèse de Doctorat], Université Paris 6, Paris, France, 1986.

[26] E. Kalnay, M. Kanamitsu, R. Kistler et al., "The NCEP/NCAR 40-year reanalysis project," Bulletin of the American Meteorological Society, vol. 77, no. 3, pp. 437-472, 1996.

[27] L. Turc, "Estimation of irrigation water requirement, potential evapotranspiration: a simple climatic formula evolved up to date," Annale Agronomique, vol. 12, no. 1, pp. 13-49, 1961.

[28] R. G. Allen, M. Smith, L. S. Perriera, and D. Raes, "A Crop évapotranspiration," FAO Irrigation and Drainage 56, 1998.

[29] E. M. Douglas, J. M. Jacobs, D. M. Sumner, and R. L. Ray, “A comparison of models for estimating potential evapotranspiration for Florida land cover types," Journal of Hydrology, vol. 373, no. 3-4, pp. 366-376, 2009.

[30] C. W. Thornthwaite, "An approach toward a rational classification of climate," Geographical Review, vol. 38, no. 1, pp. 55-94, 1948.

[31] J. Lu, G. Sun, S. G. McNulty, and D. M. Amatya, "A comparison of six potential evapotranspiration methods for regional use in the southeastern United States," Journal of the American Water Resources Association, vol. 41, no. 3, pp. 621-633, 2005.

[32] D. O. Rosenberry, T. C. Winter, D. C. Buso, and G. E. Likens, "Comparison of 15 evaporation methods applied to a small mountain lake in the northeastern USA," Journal of Hydrology, vol. 340, no. 3-4, pp. 149-166, 2007.

[33] P. Delecluse, J. Servain, C. Levy, and L. Bengtsson, "On the connection between the 1984 Atlantic warm event and the 19821983 ENSO," Tellus A, vol. 46, no. 4, pp. 448-464, 1994.

[34] L. Le Barbé, T. Lebel, and D. Tapsoba, "Rainfall variability in West Africa during the years 1950-90," Journal of Climate, vol. 15, no. 2, pp. 187-202, 2002.

[35] S. E. Nicholson and I. M. Palao, "A re-evaluation of rainfall variability in the Sahel. Part I. Characteristics of rainfall fluctuations," International Journal of Climatology, vol. 13, no. 4, pp. 371-389, 1993.

[36] L. Le Barbé and T. Lebel, "Rainfall climatology of the HAPEXSahel region during the years 1950-1990," Journal of Hydrology, vol. 188-189, no. 1-4, pp. 43-73, 1997.

[37] N. D'Amato and T. Lebel, "On the characteristics of the rainfall events in the sahel with a view to the analysis of climatic variability," International Journal of Climatology, vol. 18, no. 9, pp. 955-974, 1998.

[38] S. E. Nicholson, B. Some, and B. Kone, "An analysis of recent rainfall conditions in West Africa, including the rainy seasons of the 1997 El Nino and the 1998 La Nina years," Journal of Climate, vol. 13, no. 14, pp. 2628-2640, 2000.

[39] M. Le Lay and S. Galle, "Variabilités interannuelle et intrasaisonnière des pluies aux échelles hydrologiques. La mousson ouest- africaine en climat soudanien," Hydrological Sciences Journal, vol. 50, no. 3, pp. 509-524, 2005.

[40] T. Lebel and A. Ali, "Recent trends in the Central and Western Sahel rainfall regime (1990-2007)," Journal of Hydrology, vol. 375, no. 1-2, pp. 52-64, 2009.

[41] K. Y. Kouadio, K. E. Ali, E. P. Zahiri, and A. P. Assamoi, "Etude de la prédictibilité de la pluviométrie en Côte d'Ivoire durant la période de Juillet à Septembre," Revue Ivoirienne des Sciences et Technologie, vol. 10, pp. 117-134, 2007.

[42] S. Nicholson, "On the question of the "recovery" of the rains in the West African Sahel," Journal of Arid Environments, vol. 63, no. 3, pp. 615-641, 2005.

[43] T. Zhou, L. Zhang, and H. Li, "Changes in global land monsoon area and total rainfall accumulation over the last half century," Geophysical Research Letters, vol. 35, no. 16, Article ID L16707, 2008.

[44] L. Zhang and T. Zhou, "An assessment of monsoon precipitation changes during 1901-2001," Climate Dynamics, vol. 37, no. 1, pp. 279-296, 2011.

[45] FAO, Projet D'évaluation des Ressources Forestières Tropicales, Les ressources forestières de l'Afrique tropicale, Rome, Italy, 1981.

[46] A. Bertrand, "Ladéforestation en zone de forêt en Côte d'Ivoire," Bois et Forêts des Tropiques, no. 202, pp. 3-17, 1983.

[47] B. Liebmann, R. M. Dole, C. Jones, I. Bladé, and D. Allured, "Influence of choice of time period on global surface temperature trend estimates," Bulletin of the American Meteorological Society, vol. 91, no. 11, pp. 1485-1491, 2010.

[48] R. W. Burpee, "The origin and structure of easterly waves in the lower troposphere of north Africa," Journal of Atmospheric Sciences, vol. 29, pp. 77-90, 1972.

[49] G. Dhonneur, Nouvelles Approches des Réalités Météorologiques de L'afrique Occidentale et Centrale, ASECNA, Université de Dakar, 1978.

[50] A. Diedhiou, S. Janicot, A. Viltard, and P. De Felice, "Evidence of two regimes of easterly waves over West Africa and the tropical 
Atlantic," Geophysical Research Letters, vol. 25, no. 15, pp. 28052808, 1998.

[51] A. Diedhiou, S. Janicot, A. Viltard, P. De Felice, and H. Laurent, "Easterly wave regimes and associated convection over West Africa and tropical Atlantic: results from the NCEP/NCAR and ECMWF reanalyses," Climate Dynamics, vol. 15, no. 11, pp. 795822, 1999.

[52] J. Shukla and Y. Mintz, "Influence of land-surface evapotranspiration on the earth's climate," Science, vol. 215, no. 4539, pp. 1498-1501, 1982.

[53] V. M. A. Freitas, Les usages des sols et la valorisation de la biomasse aux tropiques, leur rôle dans le cycle global du carbone: le cas de l'Amazonie brésilienne [Thèse de Doctorat de l'Ecole des Hautes Etudes en Sciences Sociales], HESS/CIRAD, Paris, France, 1994.

[54] Y. C. Sud, J. Shukla, and Y. Mintz, "Influence of land-surface roughness on atmospheric circulation and precipitation: a sensitivity study with a general circulation model," Journal Applied Meteorology, vol. 27, pp. 1036-1088, 1988.

[55] H. Gallee and G. Schayes, "Development of a three-dimensional meso- $\gamma$ primitive equation model: katabatic winds simulation in the area of Terra Nova Bay, Antarctica," Monthly Weather Review, vol. 122, no. 4, pp. 671-685, 1994.

[56] F. Yoroba, A. Diawara, K. Y. Kouadio et al., "Analysis of the West African rainfall using a regional climate model," International Journal of Environmental Sciences, vol. 1, no. 6, pp. 1339-1349, 2011.

[57] B. Kouassi, A. Diawara, K. Y. Kouadio et al., "Numerical study of a west african squall line using a regional climate model," Atmospheric and Climate Sciences, vol. 2, 8 pages, 2012. 

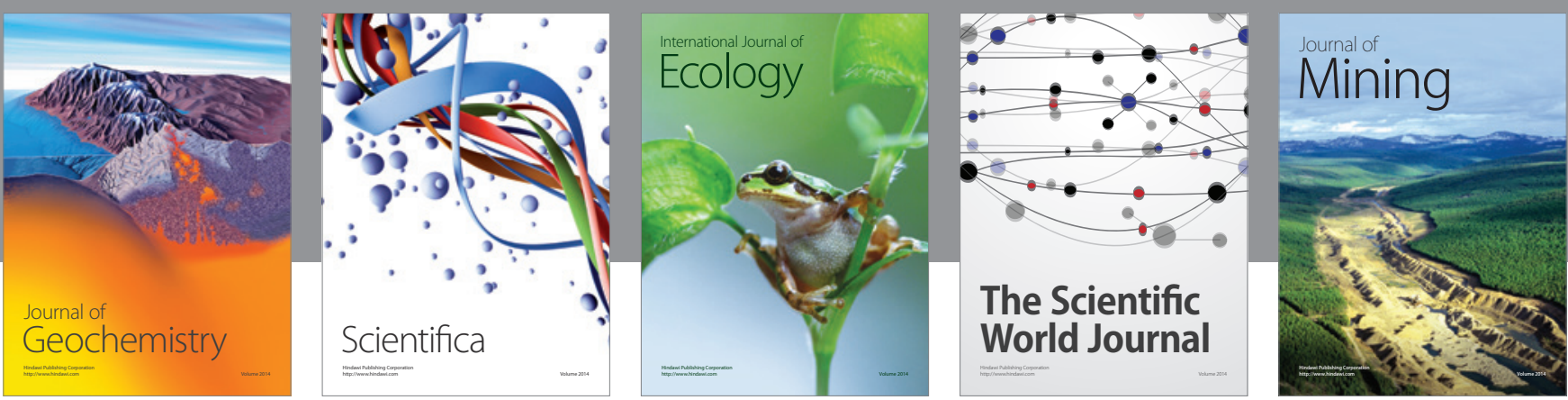

The Scientific World Journal
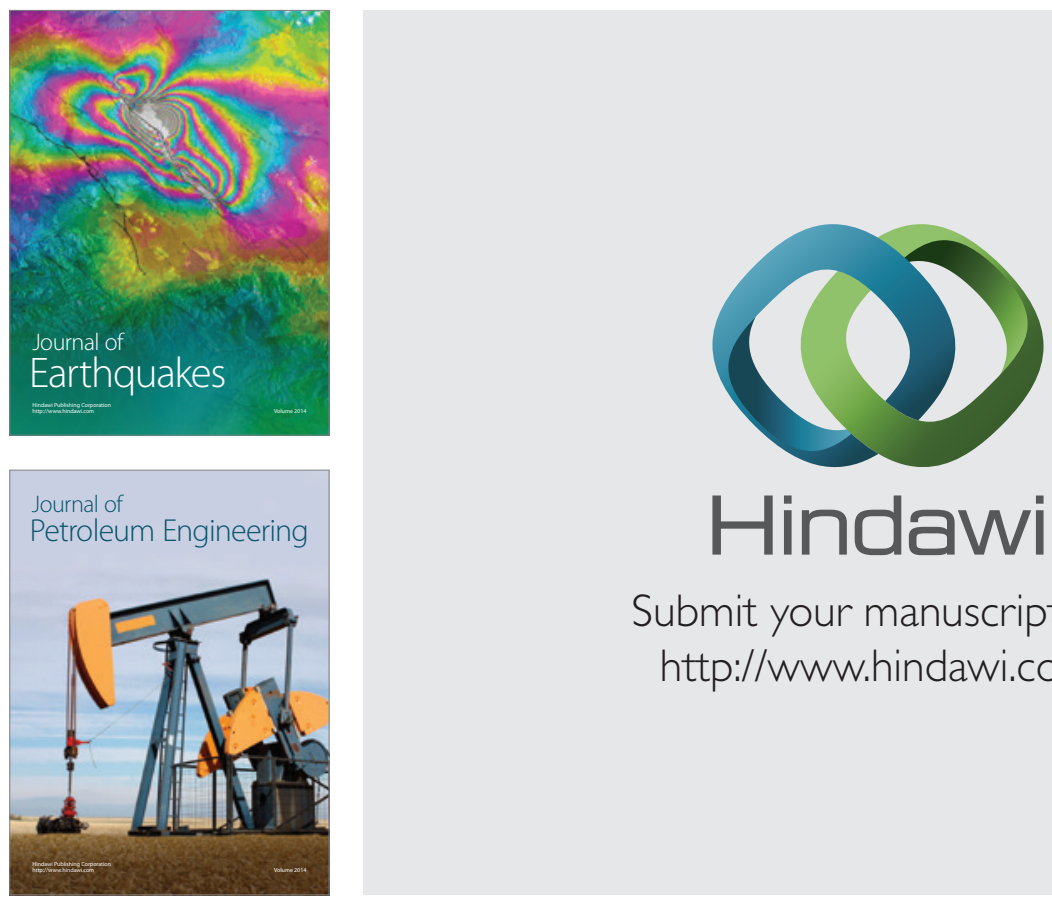

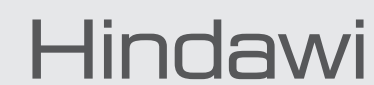

Submit your manuscripts at

http://www.hindawi.com
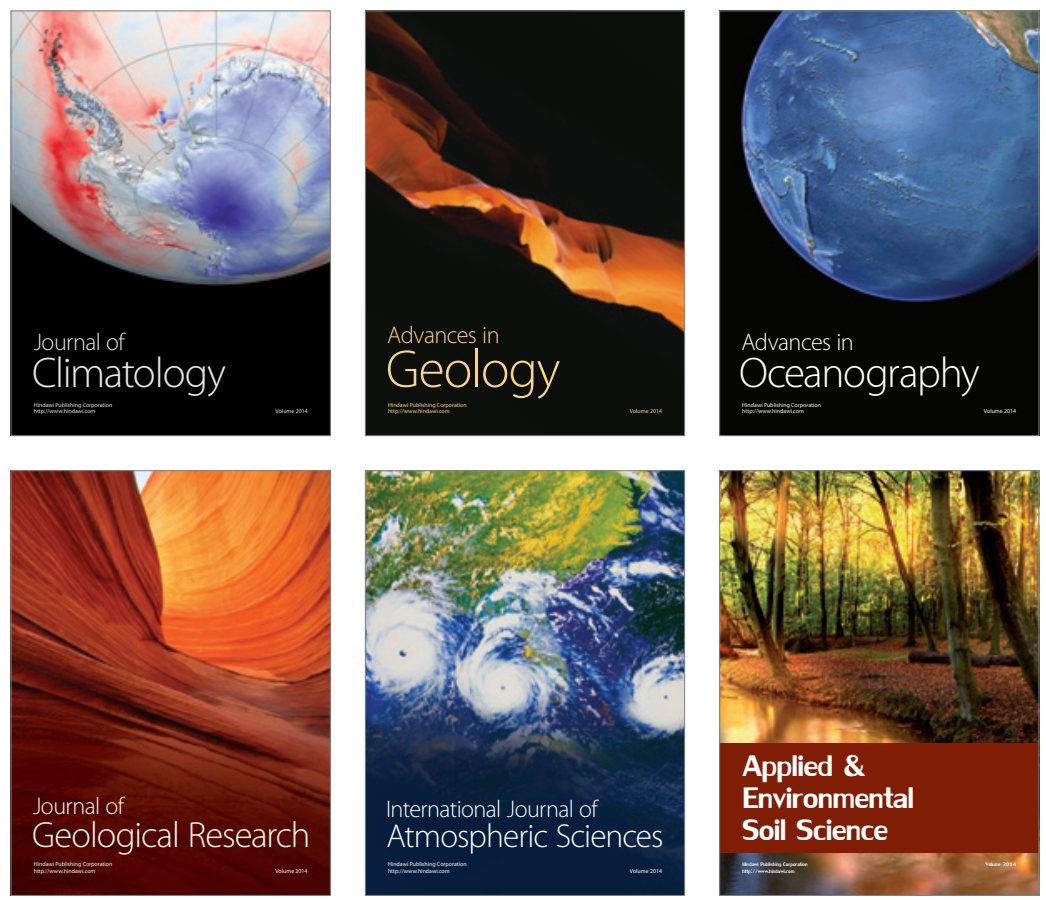
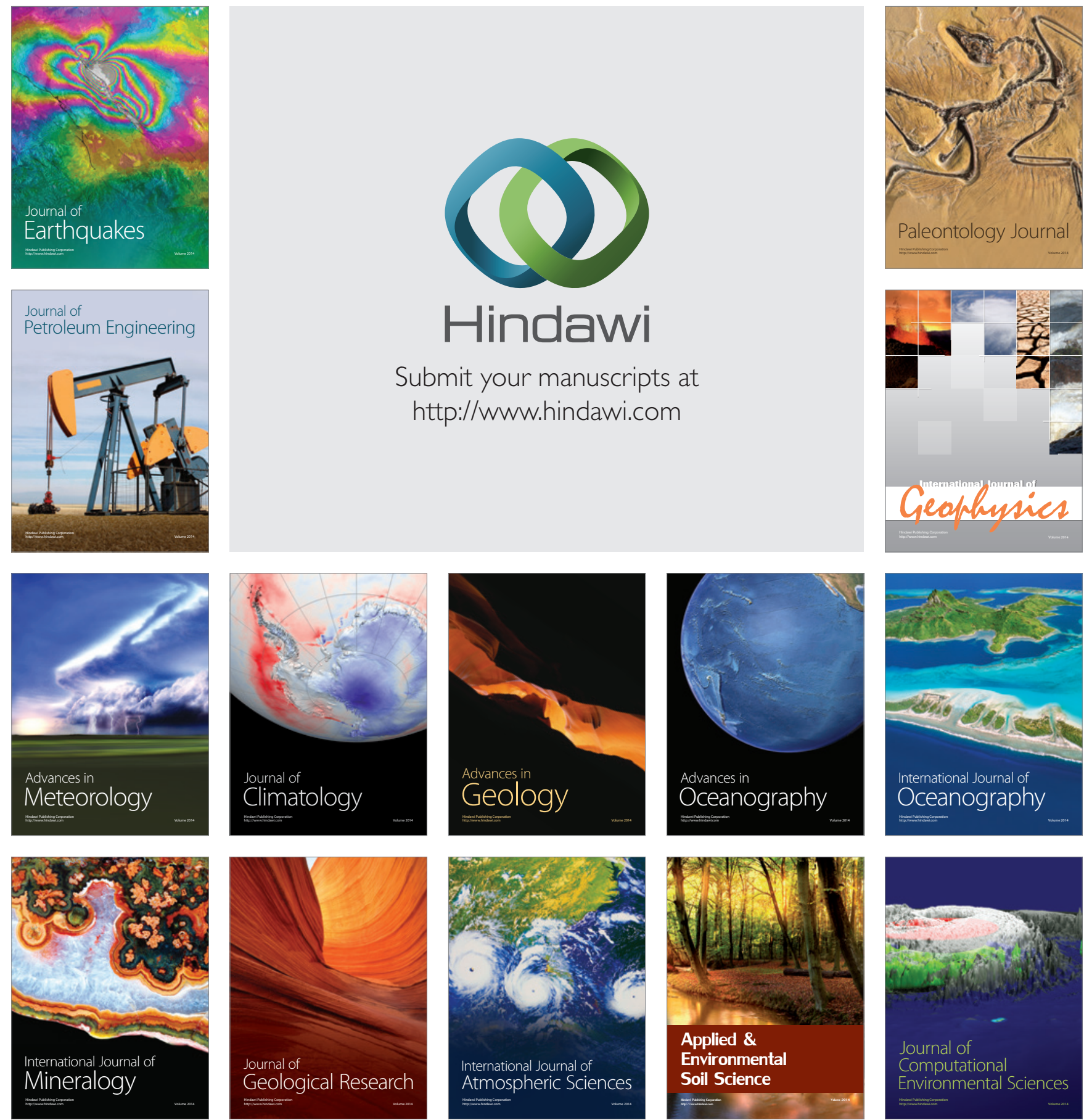